\title{
Consensus-Based Palliative Care Competencies for Undergraduate Nurses and Physicians: A Demonstrative Process with Colombian Universities
}

\author{
Tania Pastrana, MD, Roberto Wenk, MD, ${ }^{2}$ and Liliana De Lima, $\mathrm{MHA}^{3}$
}

\begin{abstract}
Background: A World Health Assembly (WHA) resolution adopted in 2014 strongly encourages member states to integrate palliative care (PC) in undergraduate training for health professionals.

Objective: The study objective was to describe a consensus-based process workshop to develop PC competences for medical and nursing schools in Colombia and to present a summary of the findings.

Methods: The workshop included 36 participants representing 16 medical and 6 nursing schools from 18 universities in Colombia. Participants were distributed in four thematic groups. Using the International Association for Hospice and Palliative Care (IAHPC) List of Essential Practices (LEP) as guidance, they were asked to discuss and define PC competencies at the undergraduate level. Participants provided feedback and approved each recommendation, and then were asked to complete an evaluation.

Results: The resulting competences were separated into six categories: (1) Definition and Principles of PC, (2) Identification and Control of Symptoms, (3) End-of-Life Care, (4) Ethical and Legal Issues, (5) Psychosocial and Spiritual Issues, and (6) Teamwork. A comparative analysis revealed that treatment of several symptoms in the IAHPC LEP (pain, dyspnea, constipation, nausea, vomit, diarrhea, delirium, and insomnia) were included in the competencies. All of the IAHPC LEP related to psychological/emotional/spiritual care was included. The evaluation rate of return was $80 \%$. The assessment was very positive: total score of $4.7 / 5.0 ; \mathrm{SD}=0.426$ ), with $89 \%$ considering the workshop to be helpful.

Conclusion: The workshop provided an opportunity for individuals from different disciplines to discuss competencies and achieve consensus. The resulting competencies will be helpful in the development of PC curricula for physicians and nurses throughout schools in Colombia and other countries.
\end{abstract}

\section{Introduction}

$\mathbf{T}$ RAINING AND FORMAL EDUCATION in palliative care (PC) is an essential component for all health care professionals. ${ }^{1}$ Education of health care workers is considered one of the crucial aspects suggested by the World Health Organization (WHO) - in addition to appropriate policies, adequate medicine availability, and service implementation-in order to advance PC in a country. ${ }^{2}$ The World Health Assembly (WHA) resolution adopted in 2014 strongly encourages member states to integrate PC in undergraduate training for health professionals. ${ }^{3}$
The need to design curricula in order to achieve desired competencies ${ }^{4}$ in health care has gained support over the past years and is advocated by the WHO, ${ }^{5}$ but has not been implemented broadly. ${ }^{6}$ The concept of 'competence' is complex $^{7}$ and has been defined in multiple ways. ${ }^{8-11}$ In this paper and throughout the project described here, we applied the following definition of competence: "Competence consists of integrated pieces of knowledge, skills and attitudes that can be used to carry out a professional task successfully.",12

In April 2014, the authors (TP, RW, LDL) visited six universities in Colombia (Universidad del Rosario, Universidad del Tolima, Universidad de Caldas, Universidad de

\footnotetext{
${ }^{1}$ Department of Palliative Medicine, Rheinisch-Westfälische Technische Hochschule Aachen, Aachen, Germany

${ }^{2}$ Fundacion FEMEBA (PAMP-FF), Argentina, San Nicolas, Argentina.

${ }^{3}$ International Association for Hospice and Palliative Care, Houston, Texas.

Accepted September 15, 2015.
}

(C) Tania Pastrana, Roberto Wenk, Liliana De Lima 2015; Published by Mary Ann Liebert, Inc. This Open Access article is distributed under the terms of the Creative Commons Attribution Noncommercial License (creativecommons.org/licenses/by-nc/4.0/) which permits any noncommercial use, distribution, and reproduction in any medium, provided the original author(s) and the source are credited. 
Manizales, Universidad Libre de Cali, and Universidad Javeriana de Cali) to have an open conversation with medical and nursing students about PC. Sessions were very well attended and generated significant interest. As a result, representatives of these universities requested our help to develop PC curricula for undergraduate medical and nursing students.

Medical and nursing schools in Colombia are responsible for the realization and mode of the curriculum for undergraduate education as long as they meet standards set by the ministry of education and the different boards. None of the boards nor the ministry of education have made PC mandatory, but a few medical schools $(<5 \%$ of the schools in the country) have included the subject for undergraduate medical education. ${ }^{13}$ To the best of our knowledge, there are no nursing schools currently offering PC courses for undergraduate students.

Based on the above and after considering the different options, the authors decided that enabling interaction and achieving consensus among the different universities was the most effective way to fill this need. To enable this project, funding from the IAHPC (United States), German Academic Exchange Service (Germany), and Fundacion de Lima Bohmer (Colombia) was secured to develop and implement a workshop in Colombia.

The purpose of the workshop was to identify PC competencies at the undergraduate level for physicians and nurses in Colombia. This paper describes a consensus-based process to develop PC core competences for medical and nursing schools in Colombia and presents a summary of the findings that resulted from this process.

\section{Methods}

This project was developed and implemented through the phases described below.

\section{Phase 0: Selection of participants}

An invitation to participate in a workshop to identify competencies for the undergraduate level in medical and nursing schools was sent via e-mail to deans and chiefs of medical and nursing programs of 18 universities. The invitation described the objectives of the workshop and invited two representatives of each university: a teacher/professor in $\mathrm{PC}$ and a person responsible for curricula development. The invitation included the dates and location as well as confirmation that the travel, accommodation, and meals would be covered. Invitees were requested to respond before a selected date to allow time for planning. Criteria for the selection of the universities were

An existing contact with the school through previous personal or academic relations

Schools that had expressed interest in developing and implementing PC programs at the undergraduate level

Schools that were teaching PC at the undergraduate level, postgraduate level, or both

A representative of the Colombian Association of Medical Faculties was invited, and the two Colombian associations for PC and a teaching hospice were represented. These NGOs were not included in the reported number of academic institutions. The group included 36 participants from 18 universities (16 medical schools and 6 nursing schools representing $33.0 \%$ and $9.5 \%$ of the corresponding schools in the country), located in eight cities (Barranquilla, Bogota, Cali, Cartagena, Ibague, Manizales, Medellin, and Santa Marta). The vast majority were physicians ( $75 \%$ versus $16 \%$ nurses and $8 \%$ psychologists) with multiple backgrounds and expertise (geriatrics, PC, family medicine, ethics, education, and psychotherapy).

\section{Phase 1: Preparatory phase for the participants}

Using the IAHPC List of Essential Practices (LEP) ${ }^{14}$ and the Recommendation of the European Association for Palliative Care (EAPC) $)^{15}$ for the Development of Undergraduate Curricula in Palliative Medicine, relevant subject areas were identified and classified in four thematic fields (see Box 1). Two weeks before the meeting, participants selected their top preferred fields and then divided among the groups according to their preferences. Participants who did not give a preference were assigned according to the composition of the groups, resulting in four groups each consisting of nine persons. At that time, in addition to the resources listed above (WHA resolution, EAPC curriculum, and IAHPC LEP), other publications, ${ }^{4,16-27}$ and relevant material ${ }^{28-31}$ were made available to all participants via a shared Dropbox folder.

\section{Phase 2: Workshop}

During the first part of the workshop, presentations were given by the authors describing the project background information with the following topics:

- WHA PC resolution, emphasizing the recommendations and member states obligations regarding $\mathrm{PC}$ education of health professionals

- PC education in Germany and Argentina as sources of comparison

- PC in Colombia, highlighting the importance of having health care professionals with the competencies to appropriately manage, treat, and refer patients

- Legal framework in Colombia regarding the provision of PC (Ley Consuelo Devis Saavedra)

- Level of student comfort regarding PC education in their own universities as based on a survey and report prepared by the authors after the visits described in the introduction section

- IAHPC LEP: development and application

- Resources from other professional associations: EAPC core curriculum and EAPC core competencies

Instructions on the method were presented and explained. The lead question was to identify in each of these thematic fields what should be performed by a general practitioner/ nurse caring for a patient with PC needs. Within the thematic fields, participants were asked to

Decide whether the topics included in each field were appropriate

Add new topics if they considered any were missing

Select the appropriate level of intervention (diagnosis and referral or diagnosis and treatment) for each topic

Participants in each group were given eight hours to discuss and make recommendations to be presented to all the participants. The authors remained in the room, facilitating the discussions and answering inquiries from the participants. 


\begin{tabular}{|c|c|c|c|}
\hline Group 1 & Group 2 & Group 3 & Group 4 \\
\hline $\begin{array}{l}\text { Basic concepts of PC } \\
\text { - Definition } \\
\text { - Aim of PC } \\
\text { - PC situation and need in } \\
\text { Colombia } \\
\text { - PC law "Consuelo Devis } \\
\text { Saavedra" } \\
\text { - Resolution WHA }\end{array}$ & $\begin{array}{l}\text { Pain } \\
\text { - Musculoskeletal, } \\
\text { visceral, neuropathic } \\
\text { - Mild to moderate, } \\
\text { moderate to severe } \\
\text { - Opioid-induced } \\
\text { neurotoxicity }\end{array}$ & $\begin{array}{l}\text { Gastrointestinal symptoms } \\
\text { - Constipation } \\
\text { - Diarrhea } \\
\text { - Nausea } \\
\text { - Vomiting }\end{array}$ & $\begin{array}{l}\text { Psychological, emotional, } \\
\text { spiritual care issues } \\
\text { - Anxiety } \\
\text { - Depression } \\
\text { - Delirium } \\
\text { - Insomnia } \\
\text { - Grief and bereavement } \\
\text { - Spiritual needs }\end{array}$ \\
\hline $\begin{array}{l}\text { Ethical and legal issues } \\
\text { - Euthanasia, assisted } \\
\text { suicide } \\
\text { - Futile medical care } \\
\text { - Patient's and family's } \\
\text { wishes discrepancy } \\
\text { - Legal issues at the end of } \\
\text { life }\end{array}$ & $\begin{array}{l}\text { Respiratory symptoms } \\
\text { - Dyspnea } \\
\text { - Respiratory secretions }\end{array}$ & $\begin{array}{l}\text { Other symptoms } \\
\text { - Anorexia-cachexia } \\
\text { - Fatigue } \\
\text { - Skin and mouth care } \\
\text { (Wounds, ulcers, dry } \\
\quad \text { mouth, etc.) }\end{array}$ & $\begin{array}{l}\text { Communication } \\
\text { - Breaking bad news } \\
\text { - Diagnostic } \\
\text { - Prognostic }\end{array}$ \\
\hline $\begin{array}{l}\text { Management } \\
\text { - Models of PC care } \\
\text { provision } \\
\text { - PC as part of the package } \\
\text { of services } \\
\text { - PC medications listed in } \\
\text { the POS }\end{array}$ & $\begin{array}{l}\text { Others } \\
\text { - National opioids } \\
\text { regulation } \\
\text { - Opioid availability and } \\
\text { distribution system } \\
\text { - Risk/detection of misuse } \\
\text { and diversion }\end{array}$ & $\begin{array}{l}\text { Others } \\
\text { - Care at the end of life } \\
\text { - Sedation } \\
\text { - Special populations }\end{array}$ & $\begin{array}{l}\text { Others } \\
- \text { Teamwork/burnout } \\
\text { - Education of patient and } \\
\text { families }\end{array}$ \\
\hline
\end{tabular}

After one day of intensive work, a representative of each group presented the results of the discussion and their recommendations. The recommendations were discussed and changes were made (if required). Each issue was discussed and unanimously approved. Some subjects, such as palliative sedation and use of opioids at the community level, generated lengthy discussions. At the end of the workshop, participants were asked to respond to three questions:

How are you going to use the results?

Who will you talk to?

When will this happen?

Based on these results and a final consensus process of the working group, the final document was constructed.

\section{Phase 3: Evaluation}

An online evaluation was sent one week after the meeting and a reminder was sent three weeks after, asking for assessment of the project organizers and the event itself (13 questions) using a Likert scale from 0 to 5 ( 0 being very bad and 5 very good). The following open questions were asked:

What went well?

What can be improved?

What was missing?

Comments

An additional question was included about the expected usefulness of the activity for implementing PC in the institution or to improve some aspects (in case implementation is currently being developed). One month later, a reminder was sent.

Quantitative data was analyzed by means of descriptive statistics using SPSS 21.0 (IBM, Armonk, NY). Free text was recorded and analyzed with the help of qualitative data analysis software MAXQDA 11 (VERBI-Consult-Sozialforschung GmbH, Berlin, Germany, 1989-2014).

\section{Results}

Using the results from phase 2, the authors divided the resulting core competences in six main categories: (1) Definition and Principles of PC, (2) Identification and Control of

\begin{tabular}{|l|} 
Box 2. CATEGORIES AND SUBCATEGORIES \\
OF THE RESUlTING CORE COMPETENCIES \\
\hline I. Definition and principles of PC \\
Definition and principles of PC \\
Models of PC \\
II. Identification and control of symptoms \\
Pain \\
Respiratory symptoms \\
Gastrointestinal symptoms \\
Insomnia \\
Delirium \\
III. End-of-life care \\
Palliative sedation \\
End-of-life care \\
IV. Ethical and legal issues \\
V. Psychosocial and spiritual issues \\
Emotional issues \\
Grief and bereavement \\
Spirituality \\
Caregiver and family \\
Communication and therapeutic relationship \\
VI. Teamwork \\
\hline
\end{tabular}


Symptoms, (3) End-of-Life Care, (4) Ethical and Legal Issues, (5) Psychosocial and Spiritual Issues, and (6) Teamwork. Box 2 shows the final outline with the main categories and subcategories. Table S1 includes the final competencies. All the participants approved the final version of the document. (See online supplementary Table S1 at www.liebertpub.com/ jpm and at www.liebertonline.com.)

\section{Evaluation}

The response rate for the evaluation was $80 \%$. The assessment was very positive, with a total score of 4.7/5.0 $(\mathrm{SD}=0.426)$ and an average between 4.6/5.0 and 4.8/5.0 for all items asked including filling the expectation (see Table 1).

Eighty-nine percent $(n=24)$ of the participants considered this activity to be helpful in the implementation of $\mathrm{PC}$ in the undergraduate curricula, or for those institutions that already have it, to improve the existing programs. There were 49 positive remarks, 25 suggestions for improvement, and 20 remarks about missed issues.

Three participants were not sure about its helpfulness ("I don't know"), as this depends on the willingness of the university to adopt changes in the curricula, especially when the process requires compromises from other specialties and deans. In addition, they fear that changes in curricula usually takes significant time and momentum may be lost.

The organization (including methodology and logistics) was rated positively, but some participants suggested smaller groups to improve discussions and interactions. Different consensus strategies were suggested: voting, virtual agreement, and templates for the formulation of competences. Suggestions included to broaden themes, include psychology and pediatric $\mathrm{PC}$, and give deeper insight into the competence concept.

The composition of the group (transdisciplinarity, diversity) and group dynamics were rated positively by all the participants. However some participants suggested a better balance between different disciplines and the participation of other institutions (such as the ministry of health). The limited expertise and knowledge regarding PC of some participants was perceived negatively. Self-criticism such as better preparation/reading of the material was also raised.

\section{Table 1. Assessment of the Event ${ }^{\mathrm{a}}$}

Mean $(S D)$

\section{Facilitator}

Command of the subject

Moderation for consensus

$4.8(0.395)$

Activity

Organization

Logistic

Contents

Methodology

Group activity

Material

Schedule

Venue

Social activity

Refreshments and lunch

Expectations

$4.6(0.688)$

$4.7(0.832)$

$4.7(0.823)$

$4.7(0.555)$

$4.6(0.636)$

$4.5(0.643)$

$4.7(0.608)$

$4.7(0.480)$

$4.8(0.423)$

$4.7(0.447)$

$4.6(0.447)$

$4.6(0.679)$

Total

$4.7(0.426)$

The initiative itself was highly rated as it related to a crucial PC need in the country and generating awareness. The process to reach a consensus was rated positively. Participants rated the results as good; however, three participants expected to reach more concrete results (i.e., a defined curriculum). Thirteen persons complained about the limited time allocated for discussions during the second day and suggested that it should be longer to enable deeper discussions. Final comments were mostly congratulations for the activity. Some participants were concerned about the continuity and implementation of this initiative and the loss of motivation and commitment for further development.

\section{Discussion}

With few exceptions, most of the published documents and resources identified in the literature and made available to the participants through the Dropbox folder were either specific for medical education or for multidisciplinary programs. There is limited literature specific to undergraduate PC curricula for nursing education.

Participants in this workshop represented several universities and different backgrounds. The resulting document includes competencies in PC for undergraduate medical and nursing students. The final document was distributed by e-mail to all the participants and translated into English. Both versions (Spanish and English) have been uploaded in the IAHPC website ${ }^{32}$ and are available to the global PC community for educational purposes.

The resulting competencies are separated in six categories: (1) Definition and Principles of PC, (2) Identification and Control of Symptoms, (3) End-of-Life Care, (4) Ethical and Legal Issues, (5) Psychosocial and Spiritual Issues, and (6) Teamwork; each includes a specific set of desired competencies. A comparative analysis reveals that identification and treatment of several of the physical symptoms included in the IAHPC LEP (pain, dyspnea, constipation, nausea, vomiting, diarrhea, delirium, and insomnia) were included in the recommended competencies. Not included were identification and treatment of wounds, ulcers, skin rash and skin lesions, dry mouth, mucositis and cough, and identification and referral of fatigue, anorexia, anemia, somnolence, and sweating.

Most of the practices related to psychological/emotional/ spiritual care needs as well as psychological distress and suffering of the relative and/or caregiver in the IAHPC LEP were included in the competencies. Depression and anxiety were not mentioned specifically, but it can be assumed they are included in the broad competence, "Recognizes the needs and emotional problems and provides support to the patients and family." Spiritual needs as well as grief and bereavement in the IAHPC LEP are also included.

On the other hand, the resulting competencies include specific competencies desired on medications (knowledge of essential medicines for PC, administration of medicines with precaution, opioid rotation, risk factors in opioid abuse, opioid equianalgesia, dilutions, conversions, and drug interactions) as well as a specific section on competencies needed for palliative sedation, including definitions, recognizing the refractory symptoms, knowledge on administration, operational aspects of sedation, and communication. None of these are included in the IAHPC LEP.

\footnotetext{
${ }^{\text {a }}$ Likert Scale from 0 to $5-0$, very bad and 5, very good.
} 
Box 3. EAPC CoRe Competencies IN PC ${ }^{33}$
1. Apply the core constituents of PC in the setting where 7. Respond to the challenges of clinical and ethical decision patients and families are based.
2. Enhance physical comfort throughout patients' disease trajectories.
3. Meet patients' psychological needs
4. Meet patients' social needs
5. Meet patients' spiritual needs
6. Respond to the needs of family carers in relation to short-, medium-, and long-term patient care goals. making in PC
8. Practice comprehensive care coordination and interdisciplinary teamwork across all settings where PC is offered
9. Develop interpersonal and communication skills appropriate to PC

EAPC, European Association for Palliative Care.

An additional analysis between the resulting competencies and the EAPC core competencies ${ }^{33,34}$ also reveals that although the structure and categorization of topics are different, most of the issues they cover are the same. The competencies are much more detailed and specific, while the EAPC core competencies are presented in broader general terms. However, the 10 categories (see Box 3) all include the competencies resulting from the workshop in Colombia.

Following Miller's pyramid of clinical competence, physicians and nurses should be able to adequately assess, evaluate, and treat patients with PC needs and refer to specialists when necessary. ${ }^{35}$ Miller's pyramid consists of four levels:

Knows: Knows some knowledge

Knows how: Knows how to apply that knowledge

Shows: Shows how to apply that knowledge

Does: Actually applies that knowledge in practice

The first two levels refer to cognition while the second two refer to doing. Research shows that the cognition zone ('knows' or 'knows how') correlates poorly with the behavior zone ('shows' or 'does'). Classroom teaching only does not lead to competence, and hence undergraduate students should also be exposed to bedside teaching, consultations, and communication sessions to be competent in PC.

The resulting list of competencies is quite comprehensive and therefore may be challenging to adopt in undergraduate programs. However, any efforts to implement a PC curriculum should include a component of showing and doing in order to ensure that physicians and nurses have the desired competencies identified by the group.

The practice and incorporation of identified competencies may result in better quality of service delivery in primary PC in Colombia and it is hoped in other countries as well. We recommend the universities and educational programs use it as a model to develop their own PC curriculum tailored to meet the needs of their patients while taking into account their own resources and the educational needs of their students. These needs may vary in different countries: in those countries where most of the students fully engage in clinical practice after graduation, teaching goals and competencies should focus mainly on clinical aspects; while in those where the students must go through a residency before their professional practice, teaching goals and competencies should balance PC philosophy, humanistic aspects of nursing and medicine, along with basic clinical competencies. In both cases, recently graduated students may become agents of change during their postbasic training.

We encourage organizations, institutions, and individuals to help distribute and promote the document, presenting it espe- cially to universities and academic decision makers. This is not a fixed document and it is open to changes, revisions, refining, and improvement according to local and national needs.

We plan to evaluate the acceptance and impact of the competencies on the quality of education, health professionals, and patients and their families. This project aims to be reproduced in other countries under an initiative called Transforming the System.

\section{Conclusion}

The workshop provided an opportunity for individuals from different disciplines (physicians, nurses, psychologists, and social workers) to discuss PC and achieve consensus. The resulting competencies will be helpful in the development of curricula for physicians and nurses throughout schools in Colombia and other countries.

\section{Acknowledgments}

This project was funded by the IAHPC (United States), the German Academic Exchange Service (Germany), Open Society Foundation (United States), the Atlantic Philanthropies (United States), and the Fundación de Lima Böhmer (Colombia).

Many thanks to the participants in this workshop: Alfonso María Valencia Caicedo, Alicia Krikorian, Angela María Benjumea Salgado, Arnoldo Bromett, Betty Sánchez de Parada, Carlos Chavarro, Clara Elisa Reyes, Claudia Buitrago, Gary Caballero, Guadalupe María Henao, Harold López, Haroldo Estrada, Jhon Jairo Botello Jaimes, John Jairo Hernández, John Jairo Vargas, John Jairo Franco, Juan Carlos Morales, Juan Carlos Hernández, Juan Guillermo Santacruz, Julián Agudelo, Laura Cardona, Lila Pérez, Luz Adriana Soto, Manuel Floyd Aldana, María Mercedes Fajardo, Marta Ximena León, Mercedes Franco, Miguel Antonio Sánchez Cárdenas, Miryan Angélica Castiblanco, Natalia García, Osvaldo Molina Olier, Rene Rodríguez, Rubby Cecilia, Luque Muñoz, Stella Urdinola, Victoria Eugenia Cabal Escandón, and Viviana Rivera Romero. It is thanks to their contribution and participation that the competencies were identified and agreed upon.

\section{Author Disclosure Statement}

No competing financial interests exist.

\section{References}

1. Tebbit P: Palliative Care 2000: Commissioning through Partnership. London, UK: National Council for Hospice and Specialist Palliative Care Services, 1999. 
2. Stjernsward J, Foley KM, Ferris FD: The public health strategy for palliative care. J Pain Symptom Manage 2007;33:486-493.

3. World Health Organization: Strengthening of palliative care as a component of integrated treatment within the continuum of care. WHO, 2014. apps.who.int/gb/ebwha/ pdf_files/EB134/B134_R7-en.pdf. (Last accessed May 20, 2015.)

4. Frenk J, Chen L, Bhutta ZA, et al.: Health professionals for a new century: Transforming education to strengthen health systems in an interdependent world. Lancet 2010;376: 1923-1958.

5. McGaghie WC, Miller GE, Sajid AW, et al.: Competencybased curriculum development on medical education: An introduction. Public Health Pap 1978:11-91.

6. Carraccio C, Wolfsthal SD, Englander R, et al.: Shifting paradigms: From Flexner to competencies. Acad Med 2002;77:361-367.

7. Stoof A, Martens RL, van Merriënboer JJG, et al.: The boundary approach of competence: A constructivist aid for understanding and using the concept of competence. Hum Resource Dev Rev 2002;1:345-365.

8. Becker R: The use of competencies in palliative care education. In: Foyle L, Hostad J, Syke N (eds): Innovations in Cancer and Palliative Care Education. Oxford, UK: Radcliffe, 2007, pp.13-23.

9. Albanese MA, Mejicano G, Mullan P, et al.: Defining characteristics of educational competencies. Med Educ 2008;42:248-255.

10. O'Donnell JF: Competencies are all the rage in education. J Cancer Educ 2004;19:74-75.

11. Epstein RM, Hundert EM: Defining and assessing professional competence. JAMA 2002;287:226-235.

12. Baartman LKJ, de Bruijn E: Integrating knowledge, skills and attitudes: Conceptualising learning processes towards vocational competence. Ed Res Rev 2011;6:125-134.

13. Pastrana T, De Lima L, Wenk R, et al.: Atlas de Cuidados Paliativos de Latinoamérica, 1st ed. Houston, TX: IAHPC Press, 2012.

14. De Lima L, Bennett MI, Murray SA, et al.: IAHPC List of Essential Practices in Palliative Care. IAHPC Press, 2012. hospicecare.com/uploads/2012/2/IAHPC\%20List\%20of\% 20Essential\%20Practices\%20in\%20Palliative\%20Care_ FINAL.pdf. (Last accessed May 20, 2015.)

15. European Association for Palliative Care Task Force on Medical Education: Recommendation of the European Association for Palliative Care for the Development of Undergraduate Curricula in Palliative Medicine at European Medical Schools. EAPC, 2013. www.eapcnet.eu/ LinkClick.aspx ?fileticket=S1MI-tuIutQ\%3d\&tabid=1717. (Last accessed May 20, 2015.)

16. Pastrana T, De Lima L, Wenk R: Estudio multicéntrico sobre la comodidad y el interés en cuidados paliativos en estudiantes de pregrado en Colombia. Med Paliativa 2014;22.

17. Wenk R, De Lima L, Mutto E, et al.: Encuentro sobre educación en cuidado paliativo en Latinoamérica: Recomendaciones sobre enseñanza en el pregrado y en el primer nivel de atención de salud. Med Paliativa 2014. [Epub ahead of print.]

18. León MX, Corredor M, Ríos F, et al.: ¿Qué perciben los estudiantes de medicina sobre sus conocimientos en dolor? Análisis de la situación en Colombia. Med Paliativa 2007;14:33-29.
19. Tovar MB, Florez D, León MX, et al.: Caracterizacion del conocimiento en cuidado paliativo pediatrico y percepcion de barreras por parte de los pediatras y residentes de pediatria. Med Paliativa. [E-pub ahead of print.]

20. Anneser J, Kunath N, Krautheim V, et al.: Needs, expectations, and concerns of medical students regarding endof-life issues before the introduction of a mandatory undergraduate palliative care curriculum. J Palliat Med 2014;17:1201-1205.

21. León MX, Florez S, Torres M: Educación en cuidado paliativo para pregrado de medicina: Resultados de una encuesta acerca de la percepción de los conocimientos adquiridos. Med Paliativa 2009;16:28-33.

22. Mutto EM, Bunge S, Vignaroli E, et al.: Medical students' palliative care education in a Latin American university: A three-year experience at Austral University in Buenos Aires, Argentina. J Palliat Med 2014;17:1137-1142.

23. Morrison LJ, Thompson BM, Gill AC: A required third-year medical student palliative care curriculum impacts knowledge and attitudes. J Palliat Med 2012;15: 784-789.

24. Pastrana T, Torres-Vigil I, De Lima L: Palliative care development in Latin America: An analysis using macro indicators. Palliat Med 2014;28:1231-1238.

25. Schiessl C, Walshe M, Wildfeuer S, et al.: Undergraduate curricula in palliative medicine: A systematic analysis based on the palliative education assessment tool. J Palliat Med 2013;16:20-30.

26. Schulz C, Moller MF, Seidler D, et al.: Evaluating an evidence-based curriculum in undergraduate palliative care education: Piloting a phase II exploratory trial for a complex intervention. BMC Med Educ 2013;13:1.

27. von Gunten CF, Mullan P, Nelesen RA, et al.: Development and evaluation of a palliative medicine curriculum for third-year medical students. J Palliat Med 2012;15:11981217.

28. Asociación Latinoamericana de Cuidados Paliativos: Currículo de Enfermería para un Programa de Postgrado en Cuidados Paliativos. Houston, TX: IAHPC Press, 2008.

29. Palliative Care Curriculum for Undergraduates Project Team: Principles for Including Palliative Care in Undergraduate Curricula. Australian Government Department of Health and Aging, Canberra, 2005. cms.qut.edu.au/_data/ assets/pdf_file/0010/196993/PCC4U-principals.pdf. (Last accessed August 11, 2015.)

30. Congreso de la Republica de Colombia: "Ley 1733 Consuelo Devis Saavedra, mediante la cual se regulan los servicios de cuidados paliativos para el manejo integral de pacientes con enfermedades terminales, crónicas, degenerativas e irreversibles en cualquier fase de la enfermedad de alto impacto en la calidad de vida. Sep 8, 2014." wsp.presidencia.gov.co/Normativa/Leyes/Documents/ LEY\%201733\%20DEL\%2008\%20DE\%20SEPTIEMBRE\% 20DE\%202014.pdf. (Last accessed August 14, 2015.)

31. Ministerio de Salud de Panama: Guía Curricular de Occidente. Contenidos curriculares para la inserción de los cuidados paliativos en los programas académicos de las facultades de las ciencias de la salud. Ciudad de Panama: Editorial Universitaria Manuel Gasteazoro, 2013.

32. De Lima L, Wenk R, Pastrana T: Transforming the system: Palliative care competencies in undergraduate education in Colombia. Houston, TX: IAHPC Press, 2014. hospicecare .com/resources/projects/competencies-in-palliative-care/. (Last accessed August 14, 2015.) 
33. Gamondi C, Larkin P, Payne S: Core competencies in palliative care: An EAPC White Paper on palliative care education. Part 1. EJPC 2013;20:86-91.

34. Gamondi C, Larkin P, Payne S: Core competencies in palliative care: An EAPC White Paper on palliative care education. Part 2. EJPC 2013;20:140-145.

35. Miller GE: The assessment of clinical skills/competence/ performance. Acad Med 1990;65:S63-S67.
Address correspondence to:

Tania Pastrana, MD

Department of Palliative Medicine

University Hospital RWTH Aachen

Pauwelsstrasse 30

52074 Aachen, Germany

E-mail: tpastrana@ukaachen.de 